\title{
PENINGKATAN HASIL BELAJAR SISWA PADA MATERI SISTEM PENCERNAAN MANUSIA MELALUI MODEL PEMBELAJARAN RESOURCE BASED LEARNING (RBL) \\ DI KELAS VIII SMP NEGERI 4 NIRUNMAS KABUPATEN MALUKU TENGGARA BARAT
}

\author{
Alexander Batmomolin ${ }^{1}$, M. Nur. Matdoan ${ }^{2}$ \\ ${ }^{1}$ Alumni Program Studi Pendidikan Biologi \\ 2Program Studi Pendidikan Biologi
}

\author{
E-mail: mnur03@gmail.com
}

\begin{abstract}
Background: In general, Biology learning in Nirunmas Maluku, West Nusa Tenggara 4 Middle School, is still teacher-centered, namely using the lecture method, so that the learning outcomes obtained by students are not maximal or inadequate for School KKM.

Method: The type of research used is descriptive, using the Resource Based Learning learning model to master the concept of the human digestive system in class VIII Nirunmas 4 Middle School. This research was conducted on February 25 - March 25, 2018.

Results: Achievement of learning outcomes before using the Resource Based Learning (RBL) learning model with an average student achievement in the initial test was $62 \%$, while after using the Resource Based Learning (RBL) learning model the average student achievement in the final test was $81,32 \%$ and the final score was $84.33 \%$.

Conclusion: There is an increase in students' understanding in the learning process using the Resource Based Learning (RBL) learning model.
\end{abstract}

Keywords: Resource Based Learning Model (RBL), learning outcomes, the concept of the human digestive system.

\begin{abstract}
Abstrak
Latar Belakang: Pada umumnya pembelajaran Biologi di SMP Negeri 4 Nirunmas Maluku Tenggara Barat, masih berpusat pada guru yaitu menggunakan metode ceramah, sehingga hasil belajar yang diperoleh siswa kurang maksimal atau tidak mencukupi KKM Sekolah.

Metode: Jenis penelitian yang digunakan adalah deskriptif, dengan menggunakan model pembelajaran Resource Based Learning terhadap penguasaan konsep sistem pencernaan manusia pada siswa kelas VIII SMP Negeri 4 Nirunmas. Penelitian ini dilaksanakan pada tanggal 25 Februari 25 Maret 2018.

Hasil: Pencapaian hasil belajar sebelum menggunakan model pembelajaran Resource Based Learning (RBL) dengan rata-rata pencapaian siswa pada tes awal adalah $62 \%$, sedangkan sesudah menggunakan model pembelajaran Resource Based Learning (RBL) rata-rata pencapaian siswa pada tes akhir adalah $81,32 \%$ dan memperoleh nilai akhir adalah $84,33 \%$.

Kesimpulan: Terdapat peningkatan pemahaman siswa dalam proses belajar dengan menggunakan model pembelajaran Resource Based Learning (RBL).
\end{abstract}

Kata Kunci: Model Resource Based Learning (RBL), hasil belajar, konsep sistem pencernaan manusia. 


\section{PENDAHULUAN}

Hasil belajar adalah indikator kualitas dan pengetahuan yang dikuasai oleh peserta didik. Prestasi belajar adalah suatu pencapain yangh diperoleh dari sebuah akumulasi nilai dari suatu proses ujian kompetensi. Hasil belajar setiap peserta didik menunjukkan suatu kemampuan atau kompetensi yang dimiliki oleh peserta didik setelah menjalani kegiatan belajar (Slameto, 2003).

Resource Based Learning (RBL) merupakan metode belajar yang secara langsung menghadapkan peserta didik dengan sejumlah sumber pembelajaran secara individu atau kelompok. Dengan menggunakan model pembelajaran seperti itu, maka pada pembelajaran biologi khususnya konsep sistem pencernaan manusia, peserta didik akan dihadapkan dengan beranekaragam sumber, seperti video, gambar, kliping, lingkungan alam, internet, dan sebagainya. Dengan penggunaan model tersebut diharapkan dapat menjadikan proses belajar mengajar lebih menyenangkan dan dapat menjadikan peserta didik menjadi proaktif sehingga proses belajar menjadi lebih efektif (Nasution, 2010).

Dalam hal mengajar guru harus pandai menggunakan pendekatan arif dan bijaksana dan bukan kebiasaan mengikuti peserta didik, karena setiap guru tidak selalu mempunyai pandangan yang sama dalam menilai peserta didik. Hal ini akan mempengaruhi pendekatan yang diambil dalam pembelajaran. Belajar berdasarkan sumber atau "Resource based learning" bukan sesuatu yang berdiri sendiri, melainkan bertalian dengan sejumlah perubahan-perubahan yang mempengaruhi pembinaan kurikulum. Perubahanperubahan itu mengenai: perubahan dalam sifat dan pola ilmu pengetahuan, perubahan dalam masyarakat dan tafsiran kita tentang tuntunannya, perubahan mengenai pengertian kita tentang anak dan cara belajarnya, perubahan dalam media komunikasi (Suryosubroto, 2009).

Pembelajaran merupakan suatu kegiatan dimana seseorang dengan sengaja diubah dan dikontrol dengan maksud agar dapat bertingkah laku atau bereaksi sesuai kondisi tertentu. Kalau dalam pendidikan di masa lalu, guru merupakan satu-satunya sumber belajar bagi peserta didik, sehingga kegiatan pendidikan cenderung masih tradisional, dan penyebaran perangkat teknologi masih sangat terbatas dan belum memasuki dunia pendidikan. Tetapi lain halnya sekarang, perangkat teknologi ada dimana-mana, pertumbuhan dan perkembangannya sangat tidak terkendali, sehingga dampaknya pun menyusup ke dalam dunia pendidikan (Hamalik, 2004).

Pembelajaran dengan hanya menggunakan satu sumber buku pelajaran sebagai pedoman dalam pelajaran, tidak relevan lagi dengan revolusi yang terjadi pada saat ini. Meskipun sampai sekarang buku pelajaran masih menjadi pilihan utama, namun guru sebagai pedoman dalam proses mengajar. Pendidikan model monologis ini tidak hanya menghalangi proses pendewasaan peserta didik secarA wajar, tetapi justru menghilangkan potensi yang di miliki oleh peserta didik. Oleh karena itu, model-model pendidikan monologis tidak relevan bila di terapkan di era globalisasi ini. Di era informasi, peserta didik setiap saat dihadapkan pada berbagai informasi dalam jumlah lebih banyak dari sebelumnya, sehingga dituntut kemampuan siswa untuk menyeleksi dan memanfaatkan sumber-sumber tertentu untuk kepentingan belajar secara optimal. Begitu pula dengan adanya kurikulum berbasis kompetensi dan kurikulum tingkat satuan pendidikan yang menuntut penggunaan berbagai sumber belajar, agar dapat memperkaya pengalaman belajar siswa (Hamzah, 2007).

peserta didik kurang semangat dalam proses belajar mengajar yaitu keterbatasan alat dan bahan yang digunakan peserta didik untuk melakukan praktikum atau percobaan di laboratorium. Hal ini mengakibatkan rendahnya pemahaman konsep dan semangat belajar pada peserta didik SMP Negeri 4 Nirunmas.

\section{MATERI DAN METODE}

Tipe penelitian ini merupakan jenis penelitian deskriptif, dengan menggunakan model pembelajaran Resource Based Learning terhadap penguasaan konsep sistem pencernaan manusia pada siswa kelas VIII SMP Negeri 4 Nirunmas. 
Penelitian dilaksanakan pada SMP Negeri 4 Nirunma.

Penelitian ini dilaksanakan pada tanggal 25 Februari sampai tanggal 25 Maret 2018 Subjek dalam penelitian ini adalah seluruh siswa kelas VIII B SMP Negeri 4 Nirunmas sebanyak 22 orang. Untuk memperoleh data penelitian, maka digunakan instrumentinstrument sebagai berikut: instrument tes, instrument non-tes. Adapun teknik pengumpulan data yang penulis gunakan adalah: teknik tes yang digunakan untuk mendapatkan data evaluasi hasil belajar pada konsep sistem pencernaan pada manusia teknik non-tes yaitu: Observasi, digunakan untuk mengamati aktifitas siswa serta mengukur kemampuan afektif dan psikomotor siswa selama proses pembelajaran, Lembar Kerja Siswa (LKS), membantu penulis dalam mengevaluasi halhal yang berhubungan dengan penguasaan konsep (aspek kognitif), juga membantu dalam memberikan penilaian kepada siswa selama proses belajar mengajar.
Analisis data yang digunakan dalam penelitian ini adalah analisis deskriptif. Skor pencapaian ketiga aspek, aspek kognitif, aspek afektif, aspek psikomotor. Menggunakan rumus:

Skor pencapaian $=\frac{\text { jumlah skor perolehan }}{\text { skor total }} \times 100$

\section{HASIL DAN PEMBAHASAN}

Deskripsi hasil belajar siswa selama kegiatan pembelajaran dengan menggunakan model Resource Based Learning. (a) Aspek kognitif dimana sebelum peneliti menggunakan model Resource Based Learning ( $\mathrm{RBL}$ ) terlebih dahulu peneliti melakukan tes awal kepada siswa, untuk mengetahui kemampuan awal siswa dalam mempelajari materi sistem pencernaan manusia, hasil yang diperoleh dapat di lihat pada tabel 1 dengan kualifikasi rata-rata presentase (\%) pencapaian siswa pada tes awal.

Tabel 1. Kualifikasi Persentase (\%) Hasil Pencapaian Siswa Pada Tes Awal

\begin{tabular}{cccc}
\hline $\begin{array}{c}\text { Tingkat Penguasaan } \\
\text { Kompetensi (\%) }\end{array}$ & Frekuensi (F) & Persentase (\%) & Kualifikasi \\
\hline $87-100$ & - & - & Sangat baik \\
$81-86$ & - & - & Baik \\
$75-80$ & - & - & Cukup \\
$<75$ & 22 & 100 & Gagal \\
\hline
\end{tabular}

Pada tabel 1 terlihat secara klasikal kemampuan siswa pada tes awal sebelum menggunakan model resource based learning berada pada kualifikasi gagal, dengan rata-rata presentase $62 \%$. Hal ini menunjukan bahwa kemampuan siswa masi rendah. Rendahnya kemampuan siswa tersebut disebabkan kerena siswa mengalami kesulitan dalam mempelajari materi sistem pencernaan manusia.

Hasil observasi pada waktu peneliti mengajar, menunjukan bahwa pembelajaran yang terjadi cenderung bersifat menonton, kurang kumunikatif, cenderung bersifat ceramah, serta siswa kurang terlibat aktif. Berdasarkan kajian awal tersebut, maka perlu sesuatu pendekatan pembelajaran yang mampu miningkatkan hasil belajar. Sehingga pembelajaran yang dimaksud adalah dengan menggunakan model pembelajaran resource based learning. 




Gambar 1. Grafik Kualifikasi Pencapaian Siswa Pada Tes Awal.

Dari gambar 1 menunjukan grafik presentase pencapaian siswa pada tes awal garis merah menunjukan nilai KKM sekolah adalah 75 sedangkan garis biru menunjukan nilai masing-masing siswa yang dicapai. Dari gambar diatas diketahui bahwa siswa $100 \%$ belum mampu melewati KKM dngan hasil yang berbeda-beda.
Setelah peneliti menggunakan model Resource Based Learning (RBL) terlebih dahulu peneliti melakukan tes awal kepada siswa, untuk mengetahui kemampuan akhir siswa dalam mempelajari materi sistem pencernaan manusia, hasil yang diperoleh dapat di lihat pada tabel 1 dengan kualifikasi rata-rata presentase (\%) pencapaian siswa pada tes akhir.

Tabel 2. Kualifikasi Persentase (\%) Hasil Pencapaian Siswa Pada Tes Akhir

\begin{tabular}{cccc}
\hline $\begin{array}{c}\text { Tingkat Penguasaan } \\
\text { Kompetensi (\%) }\end{array}$ & Frekuensi (F) & Persentase (\%) & Kualifikasi \\
\hline $90-100$ & 11 & 50 & Sangat baik \\
$81-89$ & 8 & 36,37 & Baik \\
$75-80$ & 3 & 13,63 & Cukup \\
$<75$ & - & - & - \\
\hline
\end{tabular}

Pada tabel 2 terlihat secara klasikal kemampuan siswa pada tes akhir siswa setelah menggunakan model resource based learning berada pada kualifikasi sangat baik, 11 orang siswa dengan persentase $50 \%$ dan 8 orang siswa berada pada kualifikasi baik dengan persentase 36 , $37 \%$, sedangkan 3 orang siswa berada pada kualifikasi cukup dengan persentase $13,63 \%$ dengan rata-rata persentase 86 , $61 \%$. Kemampuan aspek individu dapat dilihat pada gambar 2 . 


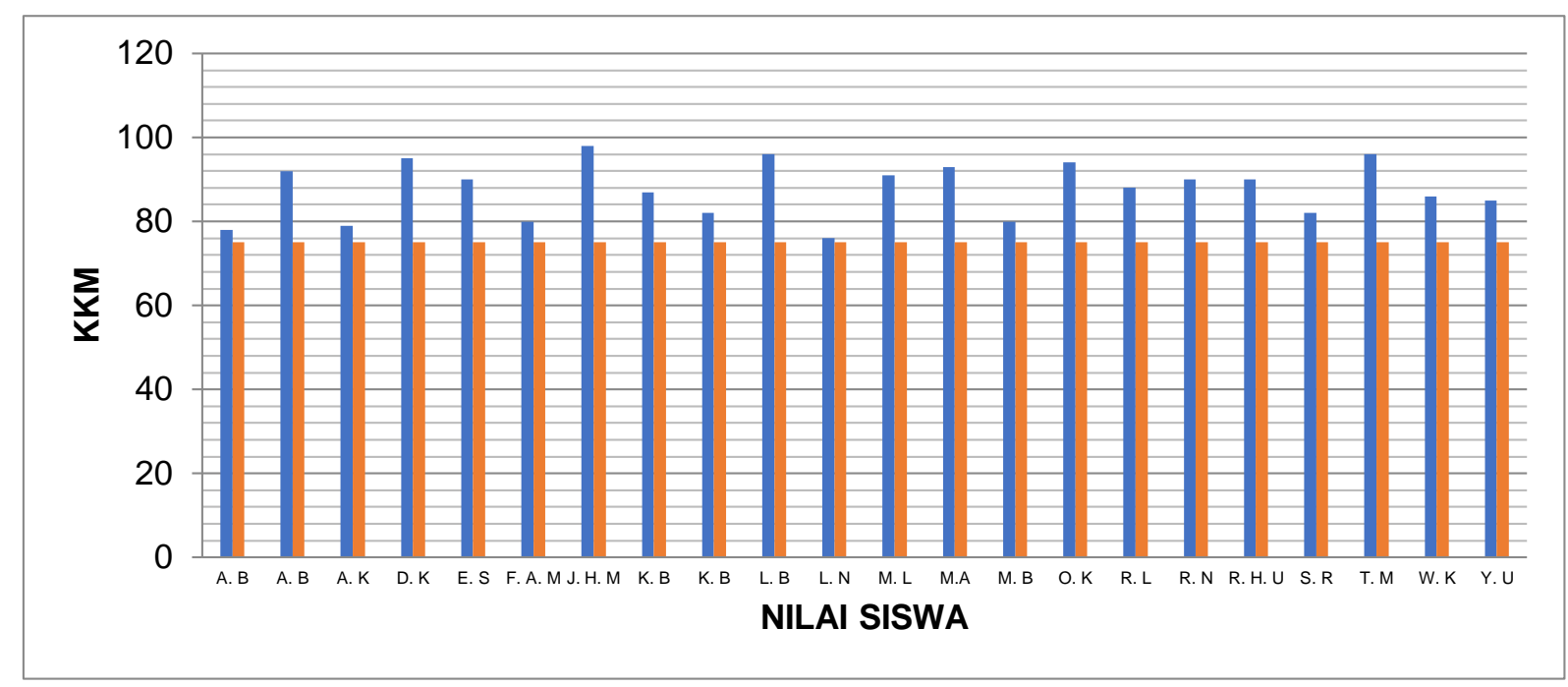

Gambar 2. Grafik Kualifikasi Pencapaian Siswa Pada Tes Akhir

Dari Gambar 2 menunjukan persentase pencapaian siswa dalam aspek kognitif pada tes akhir, garis merah menunjukan nilan KKM sekolah adalah 75 sedangkan garis biru merupakan nilai masing-masing siswa yang dicapai. Kemampuan afektif siswa dinilai menggunakan lembar observasi untuk penilaian aspek afektif, dan hasil observasinya dapat dilihat melalui lembar penilaian aspek afektif. Kualifikasi persentase pencapaian siswa dalam aspek afektif. Kualifekasi persentase pencapaian siswa dalam aspek afektif di gambarkan pada tabel 3.

Tabel 3. Kualifikasi Persentase (\%) Hasil Pencapaian Siswa Pada Aspek Afektif

\begin{tabular}{cccc}
\hline $\begin{array}{c}\text { Tingkat Penguasaan } \\
\text { Kompetensi (\%) }\end{array}$ & Frekuensi (F) & Persentase (\%) & Kualifikasi \\
\hline $87-100$ & 14 & 63,3 & Sangat baik \\
$81-86$ & 8 & 36,37 & Baik \\
$75-80$ & & & Cukup \\
$<75$ & - & - & Gagal \\
\hline
\end{tabular}

Pada tabel 3 dapat digambarkan hasil pencapaian nilai pada aspek afektif kelas VIII b berada pada kualifikasi sangat baik 11 orang siswa dengan persentase $50 \%$, dan 8 orang siswa berada pada kualifikasi baik dengan persentase 36,37\%, sedangkan 3 orang siswa berada pada kualifikasi cukup dengan persentase $13,63 \%$ dengan rata-rata persentase
$86,61 \%$. Kemampuan aspek individual dapat dilihat pada gambar 3 .

Terlihat tampak pada pesrta didik dalam berbagai tingkah laku yakni perhatiannya terhadap mata pelajaran, kedisiplinan dalam mengikuti pelajaran, serta memiliki motivasi yang tinggi untuk tahu lebih banyak mengenai pelajaran itu sendiri (Sudijono 2006). 


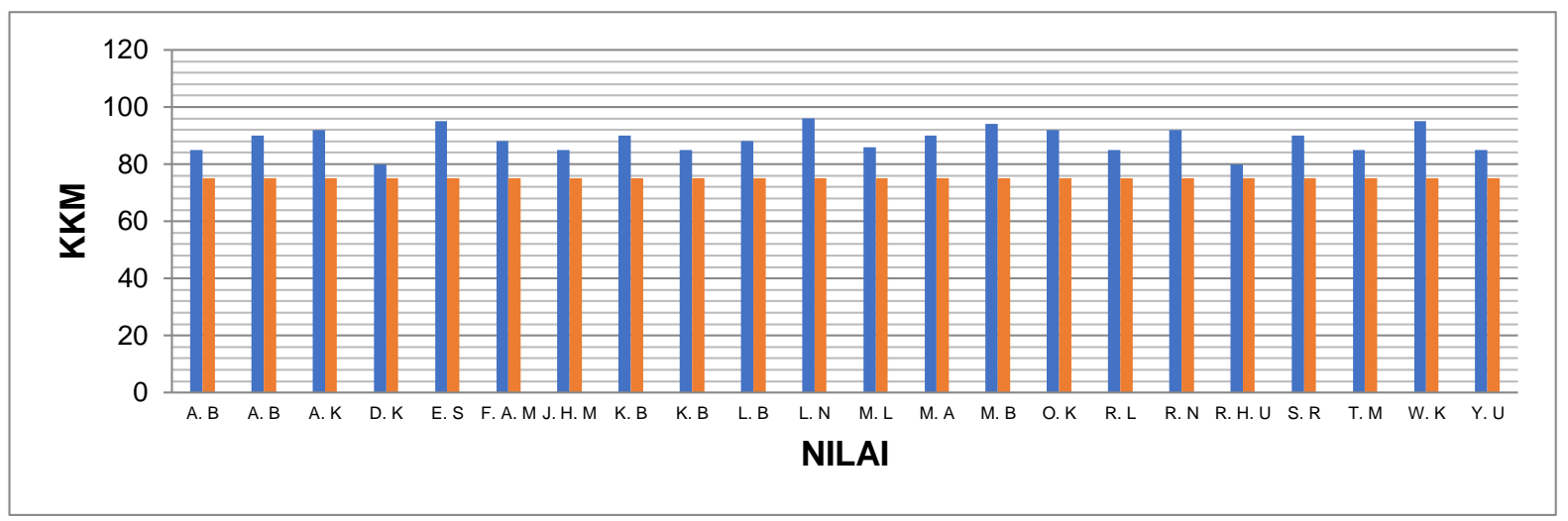

\section{Gambar 3. Persentase Pencapaian Siswa Pada Aspek Afektif}

Dari gambar 3 menunjukan persentase pencapaian siswa dalam aspek afektif, garis merah menunjukan nilai KKM sekolah adalah 75 sedangkan garis biru merupakan nilai masing-masing siswa yang dicapai. Dari gambar diatas diketahui bahwa siswa $86,37 \%$ mampu melewati KKM dengan hasil yang berbeda-beda.

Kemampuan psikomotor siswa dinilai dengan lembar observasi untuk penilaian aspek psikomotor, serta dapat dilihat dari hasil penilaian psikomotor yang diperoleh pada saat proses belajar mengajar berlangsung. Penilaian ini berkaitan dengan ketrampilan dalam menggambar, ketrampilan dalam melakukan persentase kelompok, dan juga ketrampilan dalam menjawab pertanyaan yang di tanyakan oleh teman kelompok. Kualifikasi persentase pencapaian siswa dalam aspek psikomotor digambarkan pada tabel 4 dimana hasil pencapaian nilai pada aspek psikomotor kelas VIII ${ }_{B}$ yang berada pada kualifikasi sangat baik 9 orang siswa dengan persentase $9,1 \%$ dan baik 13 orang siswa dengan persentase 90,90\%. Kemampuan psikomotor siswa secara individu dapat dilihat pada tabel 4

Tabel 4. Kualifikasi Persentase (\%) Hasil Pencapaian Siswa Pada Aspek Psikomotor

\begin{tabular}{cccc}
\hline $\begin{array}{c}\text { Tingkat Penguasaan } \\
\text { Kompetensi (\%) }\end{array}$ & Frekuensi (F) & Persentase (\%) & Kualifikasi \\
\hline $87-100$ & 9 & 9,1 & Sangat baik \\
$81-86$ & 13 & 90.90 & Baik \\
$75-80$ & - & - & Cukup \\
$<75$ & - & - & Gagal \\
\hline
\end{tabular}

Dari hasil penelitian dengan menggunakan lembaran observasi pada aspek psikomotor, menunjukan bahwa peserta didik telah menunjukan kemampuannya dalm mengikuti proses pembelajaran dengan baik. Serta dapat memperlihatkan ketrampilannya melalui gambar, ketrampilan berdiskusi, serta ketrampilan menjawab pertanyaan yang di tanyakan oleh teman kelompok (Sudijono 2006). 




\section{Gambar 4. Kualifikasi Persentase (\%) Hasil Pencapaian Siswa Pada Aspek Psikomotor.}

Dari gambar 4 menunjukan persentase pencapaian siswa dalam aspek psikomotor, garis merah menunjukan nilai KKM sekolah

adalah 75 sedangkan garis biru menunjukan nilai masing masing siswa yang dicapai.

Tabel 5. Kualifikasi Persentase (\%) Hasil Pencapaian Siswa Pada Tes Formatif

\begin{tabular}{cccc}
\hline $\begin{array}{c}\text { Tingkat Penguasaan } \\
\text { Kompetensi (\%) }\end{array}$ & Frekuensi (F) & Persentase (\%) & Kualifikasi \\
\hline $87-100$ & 2 & 30,8 & Sangat baik \\
$81-86$ & 11 & 50 & Baik \\
$75-80$ & 9 & 19,2 & Cukup \\
$<75$ & - & - & Gagal \\
\hline
\end{tabular}

Pada tabel 5 dapat digambarkan hasil pencapaian siswa pada tes formatif sebanyak 2 siswa dengan presentase $(30,8 \%)$ berada pada kualifikasi sangat baik, 11 siswa dengan presentase $(50 \%)$ berada pada kualifikasi baik, dan 9 siswa dengan presentase $(19,2)$ berada pada kualifikasi cukup. Dengan rata-rata presentase $81,32 \%$. 




\section{Gambar 5. Persentase Pencapaian Siswa Pada Tes Format}

Kualifikasi persentase (\%) pencapaian nilai akhir siswa di gambarkan pada tabel 6. nilai akhir siswa (NA) yang menggambarkan tingkat pencapaian kompetensi siswa dapat diketahui, setelah dilakukan analisis terhadap persentase pencapaian siswa dalam tes formatif ( $F)$ dan persentase pencapaian siswa dalam penilaian proses (P) pada tabel.

Tabel 6. Kualifikasi Persentase (\%) Hasil Pencapaian Siswa Pada Nilai Akhir

\begin{tabular}{cccc}
\hline $\begin{array}{c}\text { Tingkat Penguasaan } \\
\text { Kompetensi (\%) }\end{array}$ & Frekuensi (F) & Persentase (\%) & Kualifikasi \\
\hline $87-100$ & 8 & 45,9 & Sangat baik \\
$81-86$ & 14 & 64,1 & Baik \\
$75-80$ & - & - & Cukup \\
$<75$ & - & - & Gagal \\
\hline
\end{tabular}

Pada tabel 6 dapat di gambarkan hsil pencapaian siswa pada nilai akhir sebanyak 13 siswa dengan persentase (54,9\%) berada pada kualifikasi sangat baik, 14 siswa dengan persentase $(55,1 \%)$ berada pada kualifikasi baik. Dengan rata-rata persentase $86,68 \%$.

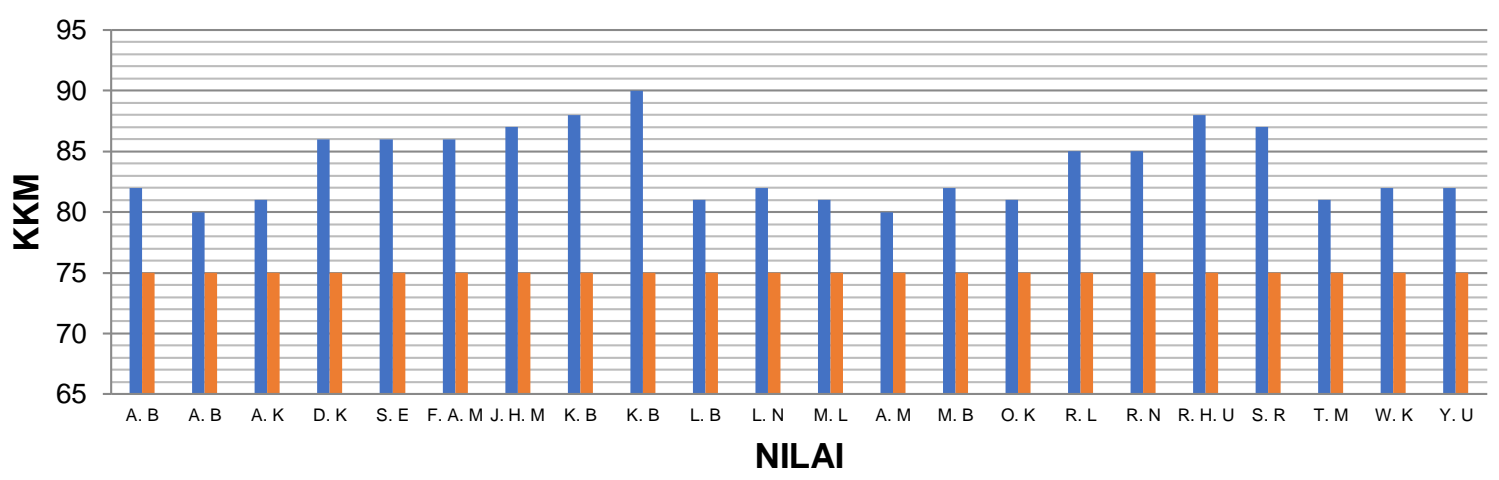

Gambar 6. Persentase Pencapaian Siswa Pada Nilai Akhir 
Dari gambar 6 menunjukan persentasi pencapaian siswa pada nilai akhir, garis merah menunjukan nilai KKM sekolah adalah 75 sedangkan garis biru menunjukan nilai masing-masing siswa yang di capai. Dari gambar diatas di ketahui bahwa bahwa siswa 100\% mampu melewati KKM dengan hasil yang berbedabeda. Pada awal pertemuan peneliti memperkenalkan model pembelajaran Resource Based Learning (RBL) kepada siswa, ketika dikenalkan ternyata siswa.

Kelas VIII pada SMP Negeri 4 Nirunmas, belum terlalu mengenal medel tersebut sehingga menimbulkan semangat siswa untuk mengetahui lebih detail tentang model yang digunakan peneliti. Resource Based Learning (RBL) adalah proses pembelajaran yang langsung menghadapkan peserta didik dengan berbagai sumber belajar secara individual atau kelompok, jadi bukan dengan cara yang konvensional di mana guru menyampaikan bahan pelajaran kepada peserta didik (Nasution, 2010). Hasil dalam penelitian ini menunjukan bahwa siswa yang diajarkan dengan menggunakan model Resource Based Learning (RBL) dipandang baik karena siswa mampu, serta mencapai hasil yang baik.

Sebelum melakukan penelitian dengan menggunakan model Resource Based Learning (RBL). Penelitian ini diawali dengan melakukan tes awal pada siswa kelas VIII SMP Negeri 4 Nirunmas. Dari hasil tes awal menunjukan 15 siswa mendapat nilai $>60$, dan 7 siswa mendapat nilai $<60$, tetapi siswa berada dalam kualifikasi gagal disebabkan karena tidak mencapai KKM (75). Hal ini menunjukan bahwa siswa belum mampu menguasai materi sistem pencernaan manusia, selain itu masi ada siswa yang pasif dan kurang fokus.

Hasil belajar kogntif meliputi penilaian terhadap pemahaman materi dan tingkat kognitif siswa. Oleh karena itu penilaian ranah kognitif ini dititkberatkan terhadap penilaian tes awal dan tes akhir. Tes awal digunakan sebagai tes diagnostik untuk mengetahui kemampuan awal siswa terhadap materi sistem pencernaan manusia. Tes ini digunakan pula untuk mengetahui tingkat kesiapan siswa dalam mengikuti proses pembelajaran. Sedangkan tes akhir digunakan untuk diagnosa pemahaman siswa setelah mengikuti proses pembelajaran melalui model pembelajaran Resource Based Learning (RBL) yang telah dilaksanakan oleh guru.Sebelum melakukan penelitian dengan menggunakan model Resource Based Learning (RBL). Penelitian ini diawali dengan melakukan tes awal pada siswa kelas VIII SMP Negeri 4 Nirunmas. Dari hasil tes awal menunjukan 15 siswa mendapat nilai $>60$, dan 7 siswa mendapat nilai $<60$, tetapi siswa berada dalam kualifikasi gagal disebabkan karena tidak mencapai KKM (75). Hal ini menunjukan bahwa siswa belum mampu menguasai materi sistem pencernaan manusia, selain itu masi ada siswa yang pasif dan kurang fokus.

Hasil tes awal yang di dapatkan oleh peneliti kurang memuaskan dikarenakan materi yang dianggap sulit oleh siswa adalah sistem pencernaan manusia, karena bagian dalam tubuh manusia tidak bisa dilihat langsung. Bagi siswa kelas VIII B yang dilakukan pada lembaga pendidikan SMP Negeri 4 Nirunmas menunujukan materi sistem pencernaan manusia tidak dapat dimengerti hanya dengan melihat buku saja, jika hanya dengan melihat buku atau mendengar penjelasan guru mereka akan hanya mengingatnya dalam jangka waktu yang pendak bahkan sebagian besar siswa sulit untuk mengerti terhadap rangsangan belajar, serta menentukan ketekunan belajar (Hamzah, 2011).

Arifin (2013) salah satu faktor yang mempengaruhi hasil belajar adalah sarana prasana termasuk didalamnya terdapat sumber-sumber pembelajaran. Selain perubahan hasil belajar, perubahan yang terlihat yaitu pada tingkah laku dan antusiasme siswa dalam mengikuti pembelajaran. Produk media pembelajaran didesain menjadi media pembelajaran interaktif yang dapat dikontrol oleh pengguna sehingga peserta didik tidak lagi pasif tetapi aktif untuk memperhatikan penjelasan guru.

Dalam proses belajar mengajar, aspek kognitif dinilai melalui tes awal dan skor pencapaiannya digambarkan dalam Tabel 2. Penilaian selama proses pembelajaran pada aspek kognitif ini menggambarkan bahwa dalam tes awal terlihat bahwa 100\% 
siswa yang berada dalam kualifikasi gagal. Suryosubroto (2009), Penilaian kemampuan tes akhir siswa dengan menggunakan model pembelajaran resource based learning (RBL) yang langsung menghadapkan pesrta didik dengan berbagai sumber belajar selama proses pembelajaran maka nilai tes akhir yang dimiliki siswa mengalami perubahan yang sangat baik. Dengan kualifikasi pencapaian siswa pada tes akhir 11 orang siswa berada pada kualifikasi sangat baik dengan persentase $50 \%$ sedangkan 8 orag siswa berada pada kualifikasi baik dengan persentase $30,8 \%$ dan 3 orang siswa berada kualifikasi cukup dengan persentase $19,2 \%$

Aspek afektif yang berhubungan dengan penilaian sikap siswa terhadap mata pelajaran dan proses pembelajaran dengan model pembelajaran Resource Based Learning (RBL), keberanian dalam menjawab pertanyaan, aktif dalam kelompok, serta dapat memberikan gagasan dan menyimpulkan pelajaran yang berbobot terlihat bahwa 100\% berhasil, baik secara klasikal maupun individual. Dengan rata-rata persentase $86,61 \%$. Hal ini menunjukan bahwa peserta didik sangat aktif dan mampu berinteraksi dengan baik. Menurut Sunender (2009), peserta didik cenderung memperlihatkan reaksi terhadap norma tertentu menunjukan kesediaan dan kerelaan untuk merespons, memperhatikan secara aktif, turut berpartisipasi dalam suatu kegiatan serta merasakan kepuasan.Menurut Syah (2009), aspek afektif (Ranah rasa) peserta didik mampu menunjukan sikap menerima atau menolak, kesediaan berpartisipasi atau terlibat, menganggap penting dan bermanfaat.

Menurut Syah (2009), aspek psikomotor dianggap tepat untuk mengevaluasi keberhasilan belajar yang berdimensi ranah psikomotor adalah observasi. Observasi dalam hal ini, dapat diartikan sebagai jenis tes mengenai peristiwa, tingkah laku, atau fenomena lain dengan pengamatan langsung.Deskripsi ini memuat tentang aspek psikomotor yaitu kertampilan dalam melakukan pengelompokan data, ketrampilan dalam memasukan data kedalam tabel, ketrampilan dalam menggambar terlihat bahwa seluruh siswa (100\%) berhasil, baik secara klasikal maupun individual. Terbukti dari rata-rata persentase $90,90 \%$, hasil yang baik ini diperoleh siswa karena selama proses kegiatan belajar mengajar biologi para siawa berantusias dalam mengikuti kegiatan pembelajaran tertentu. Menurut Dalyono (2009), peserta didik mempunyai kemampuan untuk belajar dan menggunakan apa yang telah terjadi dalam usahapenyelesaian terhadap situasi-situasi yang kurang dikenal pemecahan masalah.

Tes formatif adalah tes untuk mengukur sejauh mana siswa telah menguasai bahan pelajaran setelah mengikuti suatu program kegiatan intruksional sebagai post-test untuk mendapatkan hasil penilaian belajar yang lebih baik, maka tes formatif wajib diadakan sebelum tes sumatif (semester) oleh karena itu, perlu diuraikan agar tes formatif dapat dilaksanakan dengan baik maka banyak manfaat yang dapat dipetik oleh siswa, guru dan program itu sendiri.Dari hasil tes fomatif seorang siswa dapat mengetahui kelemahan dan keunggulannya dalam penguasaan materi pelajaran, materi man yang belum dikuasai yakni dirasakan sulit dan materi mana yang telah dikuasai dengan baik (Masidje, 2005).

Tes formatif adalah jenis penilaian yang fungsinya untuk memperbaiki proses belajar mengajar (Ahmad, 2004). Tes formatif juga merupakan tes yang diberikan kepada siswa ketika siswa tersebut telah melalui suatu proses belajar mengajar, fungsinya adalah untuk mengetahui apakah siswa tersebut memang benar-benar telah tuntas dalam mempelajari indikator-indikator pembelajaran pada materi sistem pencernaan manusia, siswa dimana sebanyak 27 siswa tuntas belajarnya walaupun memiliki nilai yang berbeda-beda dengan rata-rata pencapaian $81,32 \%$. Hal ini menunjukan bahwa peserta didik telah memahami tentang materi yang telah diajarkan serta memiliki motivasi yang tinggi. Menurut Ahmad (2004), bagi hasil yang dicapai oleh peserta didik dalam keseluruhan soal-soal tes itu dari $75 \%$ $100 \%$ maka peserta didik tersebut dianggap berhasil, telah menguasai pelajaran.

Pada tabel 4 perolehan nilai akhir setiap siswa menunjukan keberhasilan. Dengan menggunakan model pembelajaran resource based learning (RBL) dapat membantu siswa menguasai indikator 
pembelajaran pada konsep sistem pencernaan manusia. Terlihat bahwa siswa meresponi apa yang diajarkan terbukti dari rata-rata persentase adalah $84,33 \%$. Hal ini disebabkan karena peserta didik mampu menguasai indikator yang dicapai, serta memiliki keinginan untuk berhasil. Menurut Ahmad (2004), belajar yang berhasil mesti melalui berbagai macam aktivitas, baik aktivitas fisik maupun psikis. Peserta didik yang memiliki aktivitas psikis (kejiwaan) adalah, jika daya jiwanya bekerja sebanyakbanyaknya atau banyak berfungsi dalam rangka pengajaran. Seluruh peranan dan kemauan dikerahkan, diarahkan supaya daya itu tetap aktif untuk mendapatkan hasil pengajaran yang optimal sekaligus mengikuti proses pengajaran (proses perolehan hasil belajar) secara aktif.

\section{KESIMPULAN}

Berdasarkan uraian hasil penelitian dan pembehasan dapat disimpulkan bahwa penggunaan model Resource Based Learning sangat membantu siswa SMP Negeri 4 Nirunmas dalam peningkatan hasil belajar biologi pada konsep sistem pencernaan manusia.

\section{DAFTAR PUSTAKA}

Ahmad, Abu. H. \& Widodo. Supriano, 2004. Psikologi Belajar. Jakarta: Rineka Cipta.

Arifin, 2013. Evaluasi Pembelajaran. Bandung. PT Remaja Rosdakarya

Arikunto, 2002. Dasar-dasar Evaluasi Pendidikan. Jakarta: Bumi Aksara.

Dalyono, 2009. Psikologi Pendidikan. Bandung: Remaja Posdakarya Offret.

Hamalik, Oemar. 2004. Proses Belajar Mengajar. Bumi Aksara. Jakarta.

Hamzah B. 2007. Model Pembelajaran Menciptakan Proses Belajar Mengajaryang Kreatif dan Efektif. Jakarta: Bumi Aksara.

Nasution. (2010). Berbagai Pendekatan Dalam Proses Belajar Mengajar. Jakarta: PT Bumi Aksara.

Masidje, 2005. Pengukuran Presentasi Belajar. Yogyakarta

Slameto. 2003. Belajar dan Faktor-faktor yang Mempengaruhinya. Jakarta: Rineka Cipta.

Sudijono.2006. Pengantar Statistik Pendidikan. Jakarta PT Raja Grafindo Persada

Sunendar, 2009. Dasar-dasar Evaluasi Pendidikan. Jakarta PT Bumi Aksara

Suryosubroto, B, 2009 proses belajar mengajar di sekolah, Jakarta: Rineka cipta cet. II,

Syah, 2009. Psikologi Pendidikan. Bandung: Remaja Posdakarya Offret. 